\title{
Perancangan Detektor Kebocoran Gas LPG Berbasis Arduino yang Terhubung dengan Smartphone
}

\author{
Ade Mutaqin dan Erwin Sitompul \\ Program Studi Teknik Elektro, Universitas Presiden, Bekasi 17530, Indonesia \\ Penulis koresponden: sitompul@ president.ac.id
}

\begin{abstract}
ABSTRAK
LPG (Liquefied Petroleum Gas) telah menjadi bahan bakar untuk memasak bagi sebagian besar rumah tangga di Indonesia. Penggunaan LPG untuk memasak memerlukan tingkat kehati-hatian yang tinggi, karena bahaya yang dapat timbul akibat kebocoran gas ini. Bila molekul gas LPG yang mudah terbakar hadir di udara dalam suatu konsentrasi tertentu dan terdapat faktor pemicu berupa percikan atau bunga api, maka akan dapat terjadi ledakan dan kebakaran. Untuk mencegah bencana akibat kebocoran gas LPG, penulis mengajukan rancangan detektor kebocoran gas (DKG) LPG berbasis Arduino yang terhubung dengan smartphone. DKG dilengkapi dengan sensor gas MQ-2 yang mampu mengukur konsentrasi LPG di udara dalam satuan parts per million (ppm). Berdasarkan hasil pengukuran tersebut, DKG memberikan peringatan dini kebocoran LPG melalui 3 tingkat kondisi: Normal, Siaga, dan Bahaya. Setiap tingkat kondisi ditandai dengan aktivasi indikator LED, miniatur kipas sirkulasi udara, dan buzzer. Peringatan Siaga diberikan pada saat sensor membaca nilai lebih dari 400 ppm (2,05\% Ambang Ledakan Bawah LPG). Peringatan Bahaya diberikan pada bacaan lebih dari 800 ppm (4,10\% Ambang Ledakan Bawah LPG). Modul Bluetooth HC-06 menciptakan hubungan nirkabel antara DKG dan smartphone. Melalui aplikasi yang dibuat pada platform Blynk, smartphone dapat memantau konsentrasi LPG pada jarak 10 m dari DKG. DKG diuji dan berhasil untuk mendeteksi gas yang berasal dari tabung LPG dan dari korek api gas. DKG juga mampu secara sempurna menjalankan skema peringatan dini yang telah dirancang.
\end{abstract}

Kata kunci: Ambang Ledakan Bawah, Liquefied Petroleum Gas (LPG), parts per million (ppm)

\begin{abstract}
LPG (Liquefied Petroleum Gas) has become the fuel for cooking for most households in Indonesia. The use of LPG for cooking requires high level of caution, due to the danger that may arise from gas leakage. If the molecules of flammable LPG gas are present in the air at a certain concentration and there is a triggerring factor in the form of flame or sparks, explosion and fire may occur. To prevent disasters caused by a LPG gas leakage, the author proposed an Arduino-based LPG gas leak detector (GLD). The GLD is equipped with a MQ-2 gas sensor, capable of measuring the LPG concentration in air in units of parts per million (ppm). Based on the measurement result, the GLD provides an early warning of LPG leakage through 3 condition levels: Normal, Alert, and Danger. Each condition level is characterized by the activation of LED indicators, a miniature air circulation fan, and a buzzer. Alert warning is released when the sensor reads more than 400 ppm (2.05\% of LPG Lower Explosive Level). Danger warning is given at 800 ppm (4.10\% of LPG Lower Explosive Level) or higher reading. An HC-06 Bluetooth module creates a wireless connection between the GLD and a smartphone. Through an application created on Blynk platform, the smartphone can monitor the LPG concentration at a distance of $10 \mathrm{~m}$ from the GLD. The GLD is tested and succeeded to detect gases coming from an LPG cylinder and from a gas lighter. The GLD also runs perfectly for the designed early warning scheme.
\end{abstract}

Keywords: Liquefied Petroleum Gas (LPG), Lower Explosive Limit, parts per million (ppm)

\section{Pendahuluan}

LPG (Liquefied Petroleum Gas) adalah campuran gas hidrokarbon yang dicairkan, didapatkan dari hasil penyulingan minyak atau pemrosesan gas alam [1]. LPG bersifat mudah terbakar dan dipergunakan sebagai bahan bakar untuk berbagai keperluan dan tujuan, seperti perangkat pemanas udara, perangkat memasak, dan kendaraan [2].
Di Indonesia, komposisi LPG diatur oleh Direktorat Jenderal Minyak dan Gas Bumi No. 26525.K/20/DJM.T/2009 dimana produk LPG diharuskan mengandung minimal $97 \%$ propana $\left(\mathrm{C}_{3} \mathrm{H}_{8}\right)$ dan butana $\left(\mathrm{C}_{4} \mathrm{H}_{10}\right)$, dan maksimal $2 \%$ hidrokarbon lainnya [3].

LPG adalah sumber energi dengan ketersediaan yang tinggi, bersih, dan murah [4]. Hal ini turut mendorong kebijakan Pemerintah Republik Indonesia untuk melakukan 
konversi bahan bakar dari minyak tanah ke LPG pada 2007, yang didasari oleh seperangkat Undang-Undang, Peraturan Presiden, dan Peraturan Menteri ESDM [5].

Kebijakan konversi bahan bakar ini melipatgandakan jumlah rumah tangga pengguna LPG. Bila pada tahun 2007 hanya $10,57 \%$ rumah tangga menggunakan LPG sebagai bahan bakar utama untuk memasak, maka pada tahun 2016 jumlahnya meningkat menjadi $72,38 \%$ [6].

Pada masa awal konversi bahan bakar, pengguna baru LPG memerlukan waktu untuk membiasakan diri untuk menggunakan perangkat memasak yang menyertai tabung LPG, seperti unit kompor, unit selang, dan unit regulator. Berdasarkan data Badan Perlindungan Konsumen Nasional, jumlah insiden kecelakaan ledakan LPG pada tahun 2007, 2008, dan 2009 adalah berturut-turut 5, 27, dan 30 [7]. Akan tetapi, dengan sedikit memberikan perhatian, masih dengan mudah dapat ditemukan pemberitaan mengenai kecelakaan yang berhubungan dengan LPG bahkan hingga tahun 2017 sekarang ini.

Selain kemampuan untuk menggunakan seluruh perangkat dengan baik dan benar, untuk mencegah kecelakaan ledakan LPG dibutuhkan kemampuan pengguna untuk mendeteksi kebocoran yang terjadi. Sebagai alat bantu, produsen menambahkan odoran mercaptan yang berbau khas pada proses produksi LPG [2]. Keterbatasan daya cium manusia dibuktikan dengan masih terjadinya kebakaran dan ledakan akibat kebocoran LPG.

Untuk mengatasi ketergantungan terhadap daya cium manusia, dibutuhkan suatu alat yang mampu mendeteksi kehadiran LPG di udara. Alat ini diharapkan mampu memberikan peringatan dini pada saat terjadi peningkatan konsentrasi LPG yang berada di atas batas normal di udara, jauh sebelum timbul ancaman bahaya ledakan.

Sebagian besar alat pendeteksi kebocoran gas telah tersedia secara komersial tidak dilengkapi dengan antarmuka agar pengguna dapat melihat hasil pengukuran konsentrasi LPG di udara. Bila ada, untuk dapat mengetahui hasil pengukuran tersebut, pengguna harus secara fisik berada pada posisi dimana alat diletakkan. Pembacaan harus dilakukan secara langsung. Selain itu, tidak dimungkinkan untuk mengintegrasikan perangkat yang berfungsi sebagai pengurai konsentrasi LPG yang telah terakumulasi di udara, seperti kipas sirkulasi udara.

Suatu sistem pengaman kebocoran LPG yang dilengkapi dengan pemadam api diajukan oleh [8] dan [9]. Namun keduanya tidak dilengkapi dengan kemampuan untuk melakukan koneksi dengan perangkat smartphone atau pemantau jarak jauh lainnya. Putra et. al. [10] merancang alat pendeteksi kebocoran LPG yang terhubung dengan smartphone dan memberi peringatan melalui surat elektronik. Akan tetapi, pada alat tidak terpasang suatu antarmuka apapun dan alat yang diajukan memiliki dimensi yang relatif terlalu besar sehingga tidak praktis dalam penggunaannya.

Untuk memberikan pemecahan terhadap permasalahan deteksi dini kebocoran gas LPG yang dilengkapi fitur-fitur pelengkap seperti tersebut di atas, penulis mengajukan suatu rancangan detektor kebocoran gas (DKG) LPG berbasis Arduino yang terhubung dengan smartphone. DKG dilengkapi dengan kemampuan untuk memberikan peringatan dini terhadap kebocoran LPG dan kemampuan untuk mengintegrasikan perangkat pengurai konsentrasi LPG di udara saat konsentrasi gas tersebut berada di atas keadaan normal.

\section{Ambang Ledakan, Sensor Gas, DAN SPESIFIKASI DESAIN}

Ledakan LPG terjadi bila terdapat 3 hal secara bersamaan: adanya gas mudah terbakar dan oksigen dalam proporsi tertentu dan adanya sumber api seperti percikan atau bunga api. Untuk memungkinkan terjadinya ledakan, perbandingan antara suatu gas mudah terbakar dan udara harus berada di antara Ambang Ledakan Bawah (ALB) dan Ambang Ledakan Atas (ALA) dari gas yang bersangkutan [11].

Dalam hal LPG, bila kandungan LPG di udara berada di bawah ALB, maka konsentrasi LPG terlalu tipis dan adanya sumber api tidak akan menimbulkan ledakan. Pada saat kandungan LPG di udara berada di atas ALA, maka konsentrasi LPG terlalu jenuh. Kandungan oksigen di udara tidak mencukupi untuk terjadinya suatu reaksi ledakan.

LPG yang dipasarkan di Indonesia memiliki komposisi $50 \%$ propana dan $50 \%$ butana [12]. ALB dan ALA dari kedua propana, butana, dan gas LPG ditampilkan pada Tabel 1. Seluruh nilai diberikan dalam satuan \% volume. Satuan \% volume menyatakan rasio volume suatu gas dibandingkan volume seluruh gas di udara, kemudian dikalikan 100. Nilai ALB dan ALA untuk gas LPG diambil dari rerata nilai propana dan butana yang menyusun LPG dengan sama banyak.

Tabel 1. Ambang Ledakan Bawah dan Ambang Ledakan Atas Propana, Butana, dan Gas LPG [12]

\begin{tabular}{|c|c|c|}
\hline \multirow{2}{*}{ Senyawa } & \multicolumn{2}{|c|}{$\begin{array}{c}\text { Ambang Ledakan } \\
\text { (\% volume) }\end{array}$} \\
\cline { 2 - 3 } & Bawah & Atas \\
\hline Propana & 2,1 & 9,5 \\
\hline Butana & 1,8 & 8,4 \\
\hline Gas LPG & 1,95 & 8,95 \\
\hline
\end{tabular}

Salah satu sensor gas yang mampu mendeteksi keberadaan LPG di udara adalah MQ-2 (Gambar 1). Pada MQ-2 terdapat material sensor yang berubah nilai tahanan listriknya pada saat material tersebut mengalami kontak dengan gas yang berbeda konsentrasi. Sensor gas MQ-2 sensitif terhadap asap dan gas-gas mudah terbakar seperti butana, propana, metana, alkohol, hidrogen, dan karbon monoksida [13]. 


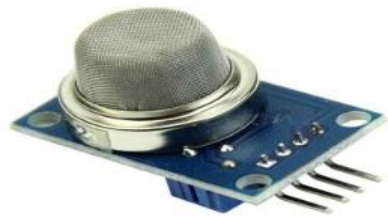

\section{Gambar 1. Sensor gas MQ-2}

MQ-2 bekerja dengan catu daya $5 \mathrm{~V}$ dan tegangan keluaran sensor gas ini berubah-ubah sesuai dengan konsentrasi tertinggi suatu gas di udara, diantara gas-gas yang dapat dideteksi olehnya. Tegangan keluaran kemudian dikonversi ke dalam satuan konsentrasi ppm (parts per million), sesuai dengan kurva kalibrasi yang dimiliki sensor gas ini. Satuan ppm sendiri menyatakan jumlah molekul suatu gas untuk setiap satu juta molekul gas yang ada. Di udara, MQ-2 dapat mendeteksi propana pada rentang 200$5.000 \mathrm{ppm}$, sedangkan butana pada rentang 300-5.000 ppm [13].

Nilai ukur sensor gas MQ-2 hanya menunjukkan perkiraan konsentrasi gas pada suatu rentang kesalahan yang dapat diterima. Untuk mengetahui konsentrasi suatu gas di udara secara pasti, diperlukan perangkat sensor profesional yang lebih akurat dan jauh lebih mahal. Namun, karena udara di atmosfer pada kondisi normal sama sekali tidak mengandung propana maupun butana, MQ-2 tetap dapat dipergunakan untuk menyatakan bahwa udara tidak berada pada keadaan normal. Hal ini terjadi apabila terdeteksi LPG pada kisaran ppm tertentu yang signifikan di atas nilai 0 . Pada keadaan ini, perlu diberikan peringatan dini sebelum ALB tercapai.

Hubungan antara Ambang Ledakan yang diberikan dalam \% volume dan konsentrasi ppm akan terlebih dahulu dinyatakan. Untuk benda gas, rasio volume identik dengan rasio molekul. Oleh karena itu, konsentrasi $1 \%$ volume setara dengan 1 molekul per seratus molekul (1 part per hundred). Selanjutnya, 1 part per hundred dapat dikonversi menjadi 10.000 parts per million (ppm).

ALB gas LPG, sesuai Tabel 1, adalah 1,95\% volume. Dengan demikian, nilai ini setara dengan 19.500 ppm. Nilai ini disebut juga 100\% ALB. Deteksi dini kebocaran LPG perlu dilakukan pada saat nilai \% ALB masih rendah.

Penulis merancang 3 tingkat kondisi kebocoran LPG, yaitu Normal, Siaga, dan Bahaya. Kondisi Normal akan berubah menjadi kondisi Siaga apabila konsentrasi LPG lebih dari 400 ppm (2,05\% ALB). Peralihan dari kondisi Siaga ke kondisi Bahaya terjadi pada konsentrasi LPG lebih dari 800 ppm (4,10\% ALB). Nilai 400 ppm dan 800 ppm adalah nilai yang rendah relatif terhadap ALB (19.500 ppm), tetapi sudah menyatakan kehadiran LPG di udara dalam proporsi yang tidak normal. Hal ini hanya dapat terjadi apabila ada kebocoran LPG.

Selain itu, penulis menggunakan satuan $\%$ relatif (\% r). Nilai ini menunjukkan persentase nilai ppm yang dibaca sensor gas MQ-2 dibandingkan dengan nilai 2.000 ppm, yang ditetapkan penulis sebagai nilai pengukuran ppm maksimal untuk dipergunakan oleh DKG.

DKG dirancang untuk memiliki antarmuka dalam bentuk LCD. LCD menampilkan nilai ppm dan nilai \% r dari hasil pengukuran sensor gas. Selain itu DKG juga dilengkapi dengan indikator LED (berwarna hijau, kuning, dan merah), buzzer, dan miniatur kipas sirkulasi udara, yang didukung oleh sebuah relay. Aktivasi dari masing-masing komponen ini dihubungkan dengan tingkat kondisi yang terjadi, seperti ditampilkan pada Tabel 2.

Tabel 2. Pembagian Kondisi Kerja DKG

\begin{tabular}{|l|c|c|c|}
\hline \multirow{2}{*}{ Output } & \multicolumn{3}{|c|}{ Kondisi } \\
\cline { 2 - 4 } & Normal & Siaga & Bahaya \\
\hline $\begin{array}{l}\text { Pembacaan } \\
\text { Sensor MQ-2 }\end{array}$ & $\begin{array}{c}\mathrm{ppm} \leq 400 \\
\% \mathrm{r} \leq 20\end{array}$ & $\begin{array}{c}400<\mathrm{ppm} \leq 800 \\
20<\% \mathrm{r} \leq 40\end{array}$ & $\begin{array}{c}\mathrm{ppm}>800 \\
\% \mathrm{r}>40\end{array}$ \\
\hline Kipas & OFF & ON & ON \\
\hline Buzzer & OFF & OFF & ON \\
\hline $\begin{array}{l}\text { Indikator } \\
\text { LED }\end{array}$ & Hijau & Kuning & Merah \\
\hline
\end{tabular}

Arduino Uno R3 dipilih sebagai pengontrol dari keseluruhan sistem DKG. Mikrokontroler ini memiliki jumlah pin dan kapasitas memori yang mampu mendukung kinerja yang diharapkan dari DKG sesuai dengan tujuan perancangannya, sesuai dengan spesifikasi yang diberikan oleh [14].

Untuk mewujudkan hubungan antara DKG dan smartphone, dipilih koneksi nirkabel dengan menggunakan teknologi Bluetooth. Salah satu modul Bluetooth yang dapat dipergunakan adalah HC-06, seperti dapat dilihat pada Gambar 2. HC-06 mempergunakan komunikasi serial UART (Universal Asynchronous Receiver/ Transmitter) untuk proses pengiriman dan penerimaan data [15]. Modul Bluetooth HC-06 hanya dapat dikonfigurasikan sebagai slave, dalam artian HC-06 tidak dapat memulai suatu koneksi. Namun apabila koneksi sudah terjadi, baik master maupun slave dapat saling bertukar informasi tanpa pembatasan tertentu.

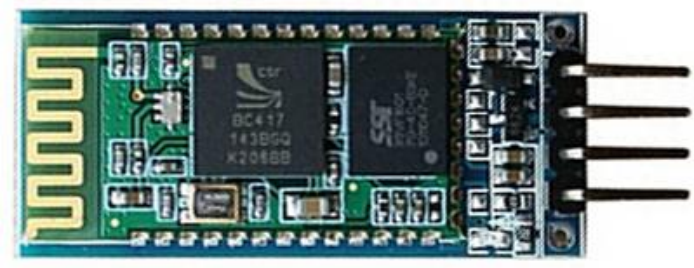

Gambar 2. Modul Bluetooth HC-06

Suatu tampilan antarmuka juga dirancang untuk ditampilkan pada layer smartphone. Tampilan ini dibentuk untuk menunjukkan nilai bacaan sensor dalam ppm, nilai $\% \mathrm{r}$, dan indikator LED.

Diagram blok DKG ditampilkan pada Gambar 3. Garis biru menyatakan aliran data sedangkan garis merah menyatakan aliran daya. 


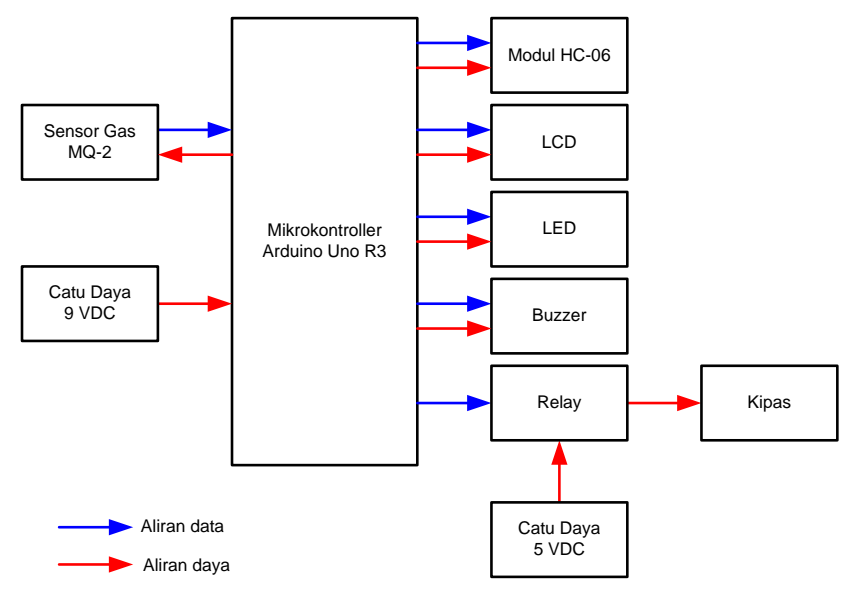

Gambar 3. Blok diagram DKG

\section{IMPLEMENTASI DESAIN}

Koneksi dari komponen-komponen penyusun DKG direalisasikan menurut Gambar 4.

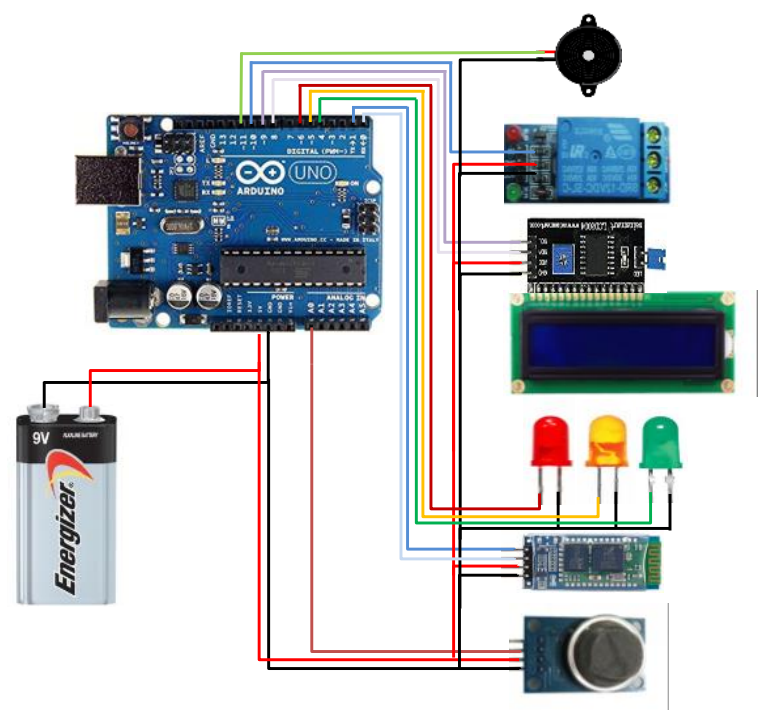

Gambar 4. Diagram koneksi
komponen-komponen DKG

Gambar 5 menunjukkan diagram alir dari sistem DKG, yang direalisasikan melalui pemrograman Arduino IDE. Setelah program dimulai dan inisiasi awal dijalankan, dilakukan pembacaan hasil pengukuran sensor. Berdasarkan tingkat kondisi yang terjadi, dilakukan aktivasi terhadap indikator LED, miniatur kipas sirkulasi udara, dan buzzer

Pada kondisi Normal, indikator LED hijau hidup. Bila kondisi berubah menjadi Siaga, maka indikator LED kuning akan hidup, disertai berputarnya kipas. Bila kondisi Bahaya tercapai, maka indikator LED merah akan hidup, kipas akan berputar, dan buzzer akan berbunyi. Selain itu, ditampilkan pesan peringatan yang menyatakan bahaya kebocoran LPG di layar LCD.

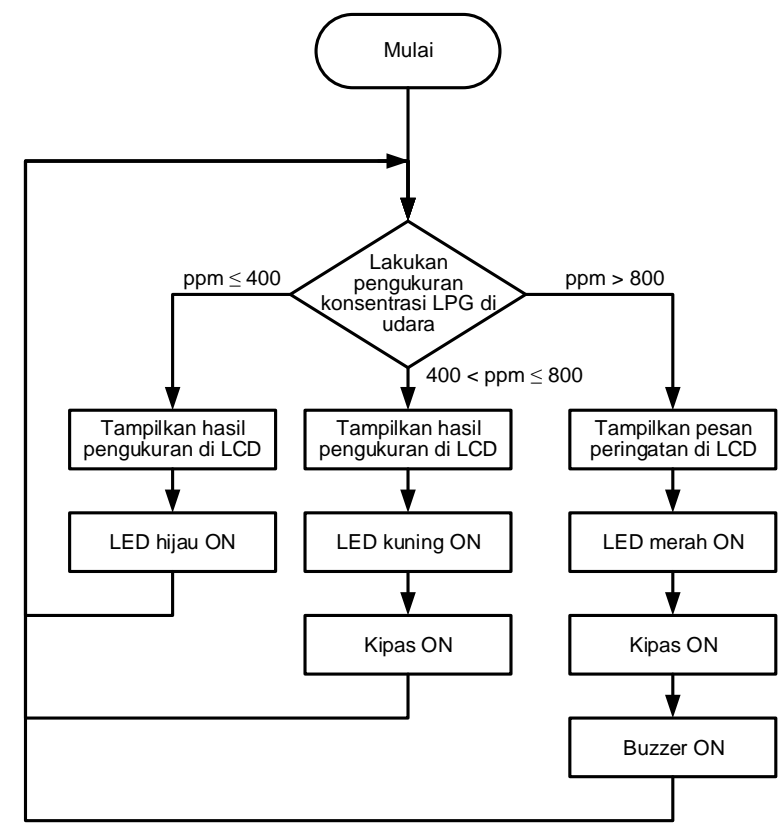

\section{Gambar 5. Diagram alir DKG}

DKG diimplementasikan dengan memiliki desain yang ringkas, dan dimensi yang kecil, sehingga mudah untuk dipergunakan dan dipindahkan. Desain prototipe DKG dapat dilihat pada Gambar 6. Ukuran kotak utama DKG adalah $15 \mathrm{~cm}$ x $8 \mathrm{~cm} \times 10 \mathrm{~cm}$. Pada bagian atas kotak utama dipasang sebuah kipas sebagai miniatur kipas sirkulasi udara.

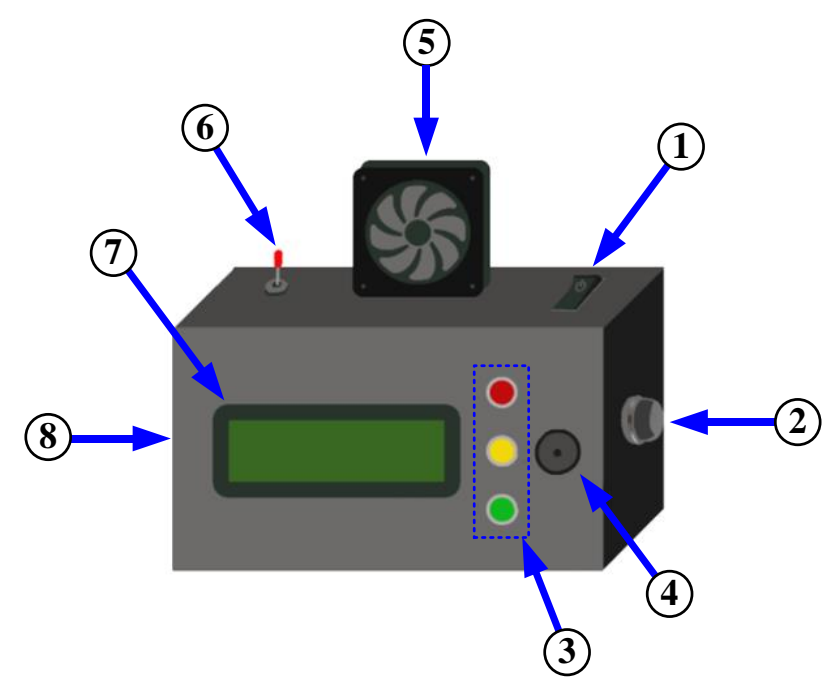

Gambar 6. Desain prototipe DKG

Saklar daya (1) berfungsi untuk menghidupkan Arduino Uno. Sensor gas MQ-2 (2) berada pada sisi kanan DKG. Pada sisi depan (3) terdapat 3 indikator LED dan sebuah buzzer (4). Kipas (5) terletak pada sisi atas, berdekatan dengan saklar kipas (6). Pengguna dapat menentukan apakah memfungsikan kipas atau tidak dengan mempergunakan saklar kipas ini. LCD (7) terletak pada sisi depan bagian depan. Catu daya (8) untuk Arduino Uno 
diletakkan pada bagian dalam kotak utama, dengan bukaan kompartemen pada sisi kiri.

Suatu aplikasi Android dirancang dengan mempergunakan platform Blynk [16]. Aplikasi ini dipergunakan untuk menampilkan hasil pengukuran konsentrasi LPG yang diterima smartphone dari DKG. Selain itu dapat dilihat indikator LED dan tren konsentrasi LPG terhadap suatu rentang waktu Aplikasi ini diberi nama "Gas Detector" dan tampilannya dapat dilihat pada Gambar 7.

Hasil pengukuran ditampilkan dalam satuan ppm (1) dan \% r (2). Pada bagian atas (3) ditampilkan indikator LED. Pada (4) ditambahkan suatu tombol reset buzzer. Tombol ini berguna untuk mematikan buzzer pada saat pengguna telah mengetahui kebocoran LPG. Dengan mematikan buzzer, dapat dihindari gangguan yang mungkin ditimbulkan buzzer pada saat pengguna melakukan tindakan penanggulangan.

Tampilan grafik hasil pengukuran berdasarkan waktu ditampilkan pada bagian bawah layar aplikasi (5). Rentang waktu tampilan grafik dapat dipilih sesuai kebutuhan, diantaranya untuk rentang waktu nyata, rentang 1 jam terakhir, hingga rentang 3 bulan terakhir. Keseluruhan hasil pengukuran disimpan dan dapat dibaca sewaktu-waktu, apabila dibutuhkan oleh pengguna.

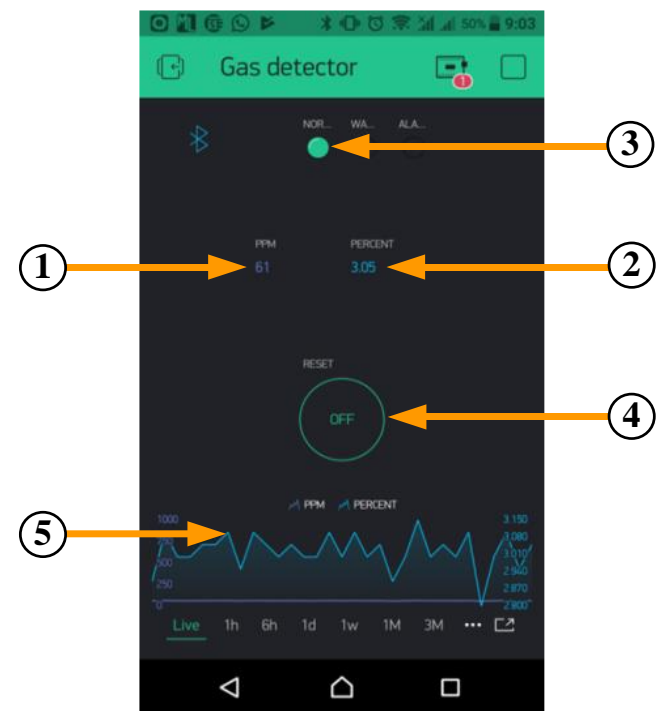

Gambar 7. Tampilan aplikasi pada Smartphone Android

\section{Hasil Pengujian dan Analisa}

\section{A. Pengujian Sensor $M Q-2$}

Pada tahap ini, sensor gas MQ-2 diuji untuk mendeteksi keberadaan LPG di udara. Pengujian ini tidak bertujuan untuk melakukan kalibrasi terhadap hasil pengukuran MQ-2, tetapi untuk melihat kemampuannya memberi tanda bahwa telah terdeteksi konsentrasi LPG pada suatu tingkat yang secara signifikan berada jauh di atas keadaan normal. Seperti telah diutarakan sebelumnya, udara atmosfer pada mengandung $\sim 0$ ppm propana dan butana, 2 senyawa hidrokarbon yang menyusun $97 \%$ gas LPG.

Dua sumber gas dicobakan untuk dibaca oleh sensor gas MQ-2, yaitu gas LPG (campuran propana dan butana) dan gas korek api (butana). Hasil pengujian ditampilkan pada Tabel 3 dan Tabel 4. Nilai \% r didapatkan dari pembacaan LCD. Tegangan pada sensor diukur dengan menggunakan multimeter.

Tabel 2. Pengujian MQ-2 Mendeteksi Gas LPG

\begin{tabular}{|c|c|c|}
\hline Percobaan & $\begin{array}{c}\text { Pembacaan } \\
\text { Sensor }(\boldsymbol{\%} \mathbf{~ r )}\end{array}$ & $\begin{array}{c}\text { Tegangan } \\
\text { MQ-2 }(\mathbf{V})\end{array}$ \\
\hline 1 & 43.64 & 4.71 \\
\hline 2 & 41.95 & 4.63 \\
\hline 3 & 45.21 & 4.79 \\
\hline 4 & 4.25 & 4.44 \\
\hline 5 & 0.54 & 4.38 \\
\hline 6 & 4.22 & 4.44 \\
\hline
\end{tabular}

Tabel 3. Pengujian MQ-2 Mendeteksi Gas Korek Api

\begin{tabular}{|c|c|c|}
\hline Percobaan & $\begin{array}{c}\text { Pembacaan } \\
\text { Sensor }(\% \mathbf{r})\end{array}$ & $\begin{array}{c}\text { Tegangan } \\
\text { MQ-2 }(\mathbf{V})\end{array}$ \\
\hline 1 & 41.84 & 4.82 \\
\hline 2 & 41.55 & 4.67 \\
\hline 3 & 41.20 & 4.71 \\
\hline 4 & 5.65 & 4.53 \\
\hline 5 & 0.94 & 4.41 \\
\hline 6 & 4.15 & 4.43 \\
\hline
\end{tabular}

Dilakukan 6 kali percobaan pada pengujian untuk masing-masing sumber gas. Pada 3 percobaan pertama dialirkan sejumlah gas hingga bacaan sensor mencapai kisaran 40\% r (800 ppm). Tegangan sensor MQ-2 diukur. Kemudian aliran gas dihentikan dan dilakukan 3 percobaan berikutnya. Nilai bacaan sensor menjadi turun ke nilai yang rendah, pada kisaran dibawah 5\% r (100 ppm, lebih rendah dari rentang 200-300 ppm kemampuan ukur MQ-2 sesuai spesifikasi sensor). Tegangan sensor MQ-2 juga diukur pada saat bersamaan.

Hasil pengujian sensor MQ-2 menunjukkan bahwa sensor ini mampu memberikan hasil pengukuran yang berubah secara signifikan pada saat terjadi aliran gas. Dengan demikian, sensor ini dapat dipergunakan sebagai pendeteksi adanya kebocoran gas. Hasil pengukuran tegangan sensor memberikan hasil yang bervariasi. Didapatkan nilai tegangan yang lebih tinggi untuk konsentrasi gas yang lebih tinggi. Akurasi pengukuran multimeter yang rendah menyebabkan nilai ini tidak dapat dipergunakan untuk mendapatkan fungsi konversi yang tepat antara tegangan sensor dan konsentrasi gas. Namun demikian, tendensi yang diperoleh telah mencukupi untuk melihat bahwa material sensor dari sensor gas MQ-2 mengalami perubahan kimiawi yang menimbulkan 
perubahan nilai resistansi, sesuai dengan gas yang mengalami kontak dengannya.

\section{B. Pengujian DKG pada 3 Tingkat Kondisi}

Pada pengujian ini, keseluruhan sistem DKG diuji dalam menghadapi 3 tingkat kondisi berbeda, yaitu kondisi Normal, kondisi Siaga, dan kondisi Bahaya. Hal ini sesuai dengan desain yang telah ditentukan sebelumnya pada Tabel 2,

Gambar 8 menampilkan keadaan pada kondisi Normal. Pengamatan dilakukan pada tampilan LCD dan tampilan layar smartphone. Pada kondisi Normal, indikator LED hijau menyala, sedangkan kipas dan buzzer pada keadaan mati. Pada LCD dan layar smartphone terlihat nilai konsentrasi LPG (19.00 ppm) dan \% r (0,95\%).

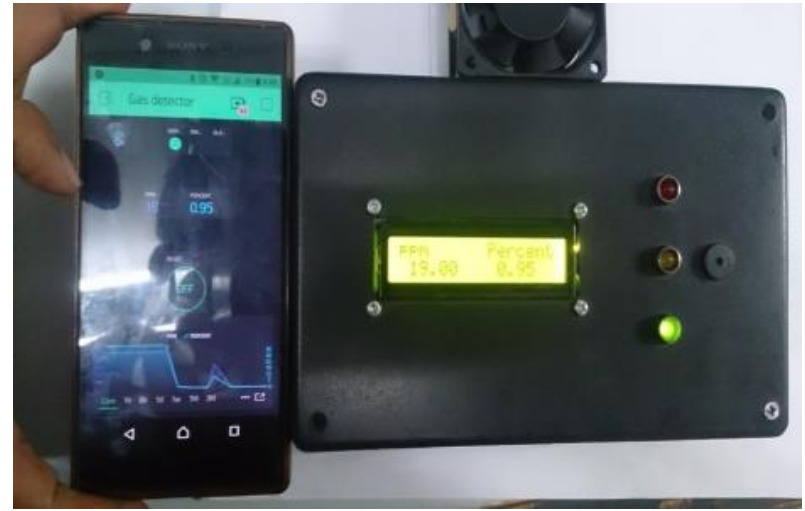

Gambar 8. Simulasi kondisi normal

Kondisi Siaga ditampilkan pada Gambar 9, dimana terbaca $256 \mathrm{pmm}$ dan $12,8 \% \mathrm{r}$ pada LCD dan layar smartphone. Pada kondisi ini indikator LED kuning menyala dan kipas berputar.

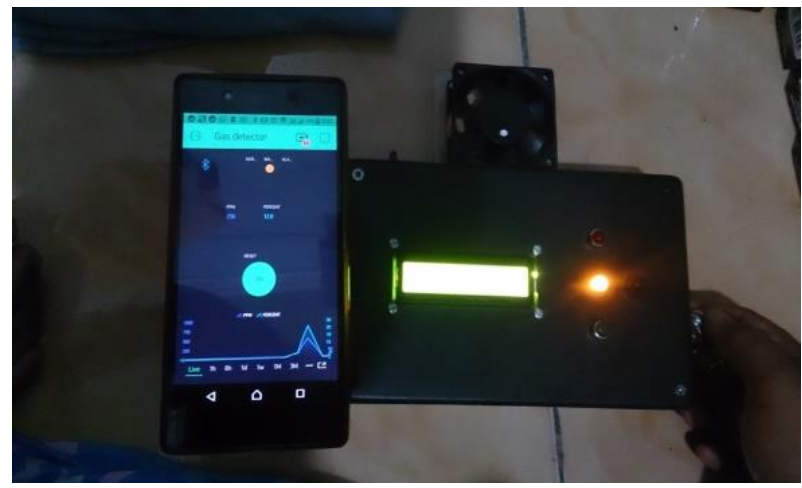

Gambar 9. Simulasi kondisi siaga

Kondisi Bahaya dapat dilihat pada Gambar 10. Konsentrasi LPG di udara berada pada 824 ppm atau $41,2 \%$ r. Pada keadaan ini indikator LED merah dan kipas menyala. Buzzer membunyikan peringatan bahaya sebagai tanda diperlukannya tindakan pencegahan dan perbaikan dengan segera. Pada LCD ditampilkan pesan peringatan yang menandakan telah terjadi kebocoran LPG.

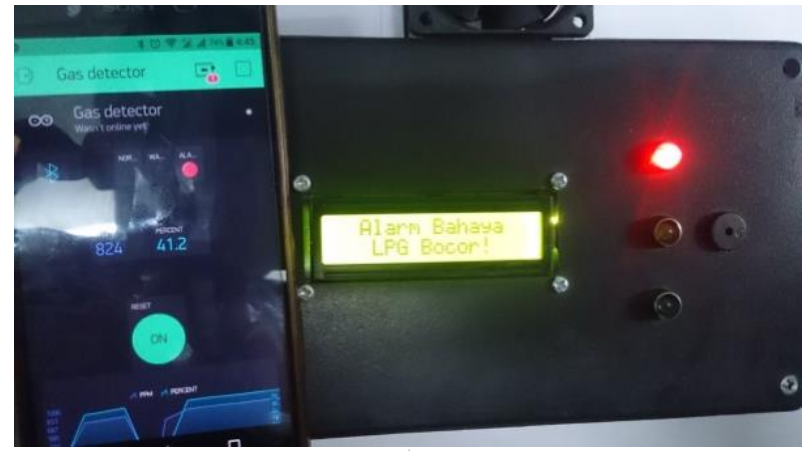

Gambar 10. Simulasi kondisi bahaya

Hasil pengujian DKG pada 3 tingkat kondisi menunjukkan bahwa keseluruhan sistem dapat bekerja sepenuhnya sesuai dengan desain awal. Indikator LED, kipas, dan buzzer bekerja sesuai tingkat kondisi yang diberikan. Selain itu, koneksi antara DKG dan smartphone dapat berlangsung dengan baik. Hasil pengukuran dan grafik waktu yang ditampilkan pada layar smartphone sepenuhnya sesuai dengan apa yang diinginkan.

\section{Analisa}

DKG yang dirancang dan diimplementasikan dalam bentuk prototipe memiliki sejumlah keunggulan sebagai berikut:

1. Pengoperasian yang mudah. Untuk memulai, pengguna cukup menekan saklar daya dan saklar kipas.

2. Antarmuka yang informatif. LCD dan layar smartphone menampilkan konsentrasi LPG dalam waktu nyata. Melalui fluktuasi hasil pengukuran yang selalu terjadi pada nilai ppm yang dapat diabaikan (0-100 ppm), pengguna dapat selalu mengetahui apakah sensor berfungsi atau tidak.

3. Perekaman hasil pengukuran. Selain ditampilkan pada layar smartphone, platform Blynk memungkinkan penyimpanan data hasil pengukuran sensor gas. Pengguna dapat lebih lanjut mempergunakan data ini, misalnya untuk melihat tren nilai pengukuran untuk rentang waktu yang berbeda.

4. Peringatan dini bertingkat. Dengan adanya 3 tingkat kondisi, DKG memberikan peringatan dini secara bergradasi. Hal ini dapat mengurangi kepanikan apabila hanya terdapat 2 tingkat kondisi saja, misalnya kondisi Normal dan kondisi Bahaya.

Sejumlah hal yang masih berpotensi untuk ditingkatkan dari DKG adalah sebagai berikut:

1. Keterbatasan jarak. Penggunaan koneksi Bluetooth membatasi jarak maksimal sekitar 10 meter antara DKG dan smartphone. Jarak ini dapat ditingkatkan dengan mempergunakan komponen yang mendukung koneksi internet, sehingga pengguna dapat selalu mengakses DKG dari mana saja. 
2. Jumlah sensor gas. Untuk kecepatan dan ketepatan pengukuran yang lebih tinggi, diperlukan lebih banyak sensor gas yang terhubung dengan DKG, yang terpasang di posisi yang berbeda dalam ruangan yang dipantau. Untuk ini diperlukan modul Bluetooth yang dapat berfungsi sebagai master pada DKG. Dengan demikian DKG dapat terkoneksi dengan dan mengkoordinasikan 6 modul lain. Masing-masing modul ini berfungsi sebagai slave dan memiliki rangkaian pendukung untuk sebuah sensor gas.

3. Kipas sirkulasi udara. Penggunaan kipas dengan kemampuan sirkulasi udara yang besar untuk menggantikan miniatur yang ada akan mempercepat terurainya konsentrasi LPG yang tinggi di udara.

\section{KESIMPULAN}

Detektor kebocoran gas (DKG) berbasis Arduino dan terhubung dengan smartphone telah berhasil dirancang dan diimplementasikan dalam bentuk suatu prototipe. DKG mempergunakan sensor gas MQ-2 untuk mendeteksi gas LPG di udara. Selain itu, dipergunakan modul Bluetooth HC-06 untuk menghubungkan DKG dan suatu perangkat smartphone.

DKG telah diuji dan mampu untuk memberikan peringatan dini pada saat konsentrasi LPG di udara mencapai 400 ppm (2,05\% Ambang Ledakan Bawah) dan 800 ppm (4,05\% Ambang Ledakan Bawah). Penggunaan indikator LED, miniatur kipas sirkulasi udara, dan buzzer turut mendukung tersampaikannya peringatan dini dengan baik kepada pengguna.

Smartphone yang terhubung dengan DKG mempergunakan koneksi Bluetooth mempermudah pengguna untuk mengetahui hasil pengukuran konsentrasi gas tanpa harus membaca langsung dari LCD yang terdapat pada DKG. Selain itu, terdapat fasilitas perekaman data hasil pengukuran, sehingga data ini dapat dipergunakan oleh pengguna untuk suatu keperluan lebih lanjut.

DKG menjadi prototipe yang telah didemonstrasikan dalam lingkungan sebenarnya, setara dengan Tingkat Kesiapterapan Teknologi (TKT 7) [17]. Melalui sejumlah perbaikan, DKG berpotensi untuk memiliki kemampuan yang jauh lebih baik, untuk kemudian berproses untuk mencapai TKT yang lebih tinggi dan menjadi suatu alat yang dapat diproduksi secara massal.

\section{DAfTAR PUStaka}

[1] H. Devold, Oil and Gas Production Handbook: An Introduction to Oil and Gas Production, Transport, Refining, and Petrochemical Industry, ABB, 2013.

[2] Kosan Crisplant, Understanding LPG - Your Guide to LPG Basics, Kosan Crisplant, 2016.

[3] M. H. Syukur, Penggunaan Liquefied Petroleum Gases (LPG): Upaya Mengurangi Kecelakaan Akibat LPG, Forum Teknologi, Vol. 01, No.2, 2011

[4] Grand View Research, Liquefied Petroleum Gas (LPG) Market Share, Size, and Trend Analysis Report By Source, Grand View Research, October 1, 2016. [Online]. Available: https://www. grandviewresearch.com. [Accessed December 1, 2016].

[5] Direktorat Jenderal Minyak dan Gas Bumi, Konversi Mitan ke Gas, Kementerian ESDM. [Online]. Available: https://migas.esdm.go.id. [Accessed March 14, 2016].

[6] Badan Pusat Statistik, Persentase Rumah Tangga Menurut Provinsi dan Bahan Bakar Utama untuk Memasak Tahun 2001, 2007-2016, Badan Pusat Statistik, January 14, 2016. [Online]. Available: https://www.bps.go.id. [Accessed March 8, 2016].

[7] Detik Finance, Ledakan Elpiji Paling Banyak di Jakarta, Detik.com, July, 1, 2010. [Online]. Available: https://detik.com. [Accessed March 14, 2016].

[8] S. M. Mendonca, G. S. Fernando, B. Mahfud, dan Pramulyoni, Sistem Pengaman Kebocoran Liquefied Petroleum Gas (LPG) dan Pemadam Api Pada Rumah Makan/Restoran, Widya Teknika, Vol. 21, No. 2, pp. 19-26, 2013

[9] A. S. Burhan, Muljoni, dan E. Syamsuddin, Alat Pencegahan Kebakaran yang Disebabkan Kebocoran Liquefied Petroleum Gas (LPG), Tesla, Vol. 15, No. 2, 2013.

[10] M. F. Putra, A. H. Kridalaksana, dan Z. Arifin, Rancang Bangun Alat Pendeteksi Kebocoran Gas LPG Dengan Sensor MQ-6 Berbasis Mikrokontroler Melalui Smartphone Android Sebagai Media Informasi, Jurnal Informatika Mulawarman, Vol. 12, No. 1, 2017.

[11] C. Yaws, Matheson Gas Data Book, McGraw-Hill Professional, $7^{\text {th }}$ Edition, 2001.

[12] Direktorat Jenderal Minyak dan Gas Bumi, Komposisi LPG Tidak Berubah, Kementerian ESDM, October 1, 2010. [Online]. Available: https://migas.esdm.go.id. [Accessed March 14, 2016].

[13] Hanwei Electronics, Technical Data: MQ-2 Gas Sensor.[Online]. Available: http://www.hwsensor.com. [Accessed February 29, 2016].

[14] Arduino, Arduino Uno R3 Data Sheet. [Online]. Availabe: https://store.arduino.cc. [Accessed October 1, 2016].

[15] Guangzhou HC Information Technology, HC-06 Product Data Sheet, April 6, 2011. [Online]. Available: http://www.wavesen.com. [Accessed July 5, 2015].

[16] Blynk Inc., We make Internet of Things simple for you, 2016. [Online]. Available: https://blynk.io. [Accessed July 10, 2016]

[17] Kemenristekdikti, Peraturan Menteri Riset, Teknologi, dan Pendidikan Tinggi Nomor 42 Tahun 2016 tentang Pengukuran dan Penetapan Tingkat Kesiapterapan Teknologi, July 1, 2016. [Online]. Available: https://risbang.ristekbrin.go.id. [Accessed September 1, 2016]. 